\title{
Financial Performance Islamic Banking: A Comparative Analysis Before and During the Covid-19 Pandemic in Indonesia
}

\author{
Mister Candera \& Karina Dwi Indah \\ Universitas Muhammadiyah Palembang, Indonesia \\ Email: mister.candera@gmail.com
}

\begin{abstract}
The Covid 19 pandemic which spread to all countries in the world including Indonesia, caused various economic sectors, especially the financial sector, to be shaken. Especially at the beginning of the Covid 19 case, almost all sectors of the economy were paralyzed. Government regulations prohibiting non-essential activities outside the home, restricting operations in several vital sectors, and prohibiting crowds, add to the long list of causes for the weak performance of the financial sector. However, the Islamic banking financial sector was not too affected as evidenced by the financial performance of Islamic banking which was still in a good category. So it is necessary to further investigate the differences in the financial performance of Islamic banking before and during the Covid 19 pandemic in Indonesia. The data used in this study are secondary data collected through documentation. The number of samples studied was 34 Islamic banking consisting of 14 Islamic Commercial Banks and 20 Islamic Business Units. The data analysis used was the Multivariate Analysis of Variance (MANOVA) analysis. The results of the analysis show that there are differences in the financial performance of Islamic banking before and during the COVID-19 pandemic in Indonesia. In addition, before and during the Covid 19 pandemic had a significant effect on Islamic banking financial performance consisting of Non Performing Finance (NPF), Capital Adequacy Ratio (CAR), and Return On Assets (ROA).
\end{abstract}

Keywords financial performance, before and during the Covid 19 Pandemic

\section{Introduction}

Currently the world economy is experiencing a very serious challenge, which is caused by the spread of Coronavirus Disease 19 which has infected almost all countries in the world, including Indonesia. Coronavirus Disease 19 or often abbreviated as covid-19 is a new virus that has emerged since the end of 2019 with the first case in Wuhan, Hubei Province, China. The spread of this virus is classified as very fast so that it is a very serious threat. Spread through direct or indirect contact makes this virus the number one killer in the world in 2020. Until now, the number of deaths caused by the corona virus in the world is 2.53 million, while the number of deaths in Indonesia is 35,981 . This number is quite high when compared to other ASEAN countries.

In Indonesia, the current coronavirus has resulted in an increase in the number of poor people. Even the Institute for Demographic and Property Studies (IDEAS) predicts that poverty in Indonesia caused by this pandemic will reach $15 \%$, which was initially only $9.22 \%$.

As a result of the Covid 19 pandemic, various business sectors have had a negative impact. Almost all sectors, such as tourism, manufacturing, automotive, property, hotels and restaurants, finance, and even MSMEs, experienced a decline in income. The company's financial performance has become unstable. However, there is one sector that has a fairly resilient financial performance in facing the Covid 19 pandemic so that it does not experience a significant decline when compared to other business sectors, namely Islamic banking.

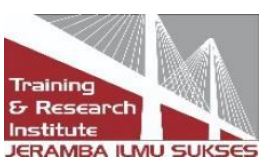


In an online newspaper (republika) states that Islamic banking is able to grow well even though it is in a COVID-19 pandemic situation. Sharia banking tends to have a relatively small risk during a pandemic due to the concept of fairness, transparency and benefit which indirectly mitigates consequences arising from the covid 19 pandemic. This can be proven from the financial performance of Islamic banking. Financial performance is an analysis used to measure whether the company has been successful in carrying out company management properly and based on the rules that apply in a certain period.

In this study, the financial performance used is the financial ratio consisting of the liquidity ratio as reflected by the Non Performing Financing (NPF) variable, the solvency ratio reflected by the Capital Adequacy Ratio (CAR) variable, and the profitability ratio reflected by the Return On Assets variable. (ROA) (Kasmir, 2014). The data on the development of Islamic banking financial performance can be seen in the following figure.

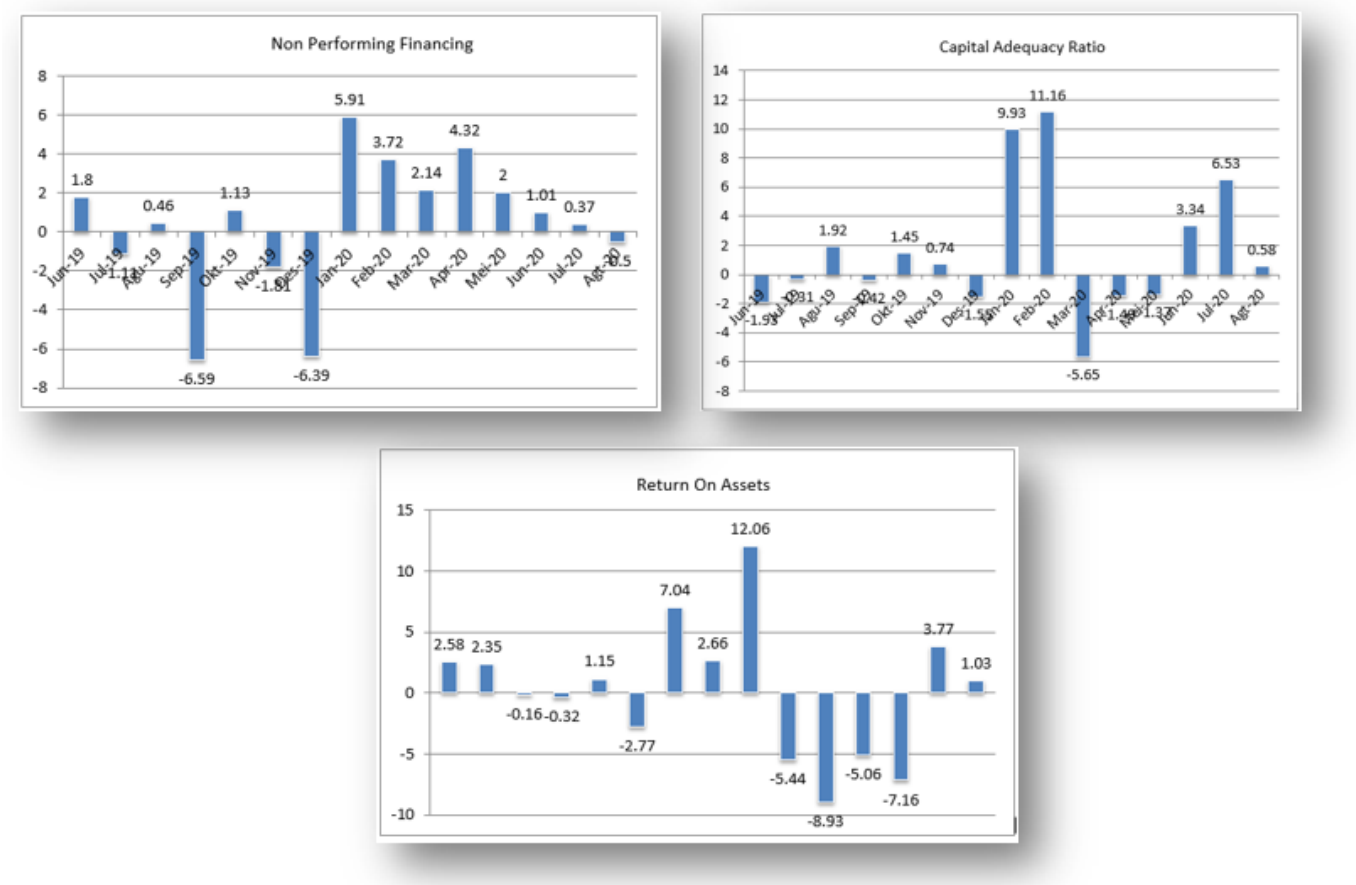

Figure 1. Sharia Banking Financial Performance in Indonesia, June 2019 to August 2020

Figure 1 above shows the development of financial performance consisting of Non-Performing Financing (NPF), Capital Adequacy Ratio (CAR), and Return on Assets (ROA). From this figure, the development of the NPF from June 2019 to August 2020 has fluctuated. Before the Covid 19 pandemic, the lowest NPF of Islamic banking occurred in September, which was 6.59 , which means that the quality of distributed financing had increased, but in January 2020 the NPF increased to $5.91 \%$, indicating that in that month the financing experiencing problems or an increase in problematic financing. Meanwhile, at the time of the Covid 19 pandemic in Indonesia, the highest NPF occurred in April 2020 at 4.32\%. This figure is lower than the NPF in January 2020, however, it provides a negative signal for the financial performance of Islamic banking. In the following months, Islamic banking succeeded in reducing the NPF by $-0.5 \%$ in August 2020.

Capital Adequacy Ratio (CAR) shows the quality of capital owned by Islamic Banking. The higher the CAR, the better the capital capacity of the bank itself. From the data in Figure 1 above, it shows that the highest CAR before the Covid 19 pandemic, namely in February 2020

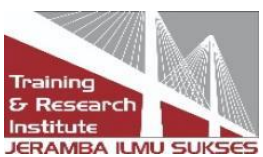


was $11.16 \%$. The lowest value occurred in June 2019 , namely $-1.93 \%$. Meanwhile, since the Covid 19 pandemic, CAR has experienced a very sharp decline in March 2020 by $-5.65 \%$. This illustrates that at the beginning of the Covid 19 pandemic, Islamic banking capital experienced significant problems due to domestic economic shocks. In the early days of the pandemic, the government aggressively reduced community activities outside, including in the financial sector.

Return On Assets (ROA) shows the efficiency of assets, the higher the ROA, the better the asset efficiency. Based on the data in Figure 1 above, it shows that before and during the pandemic ROA experienced unstable fluctuations. Before the Covid 19 pandemic, the ROA value decreased only at -2.77 , while after the Covid 19 pandemic the ROA value decreased to -8.93 .

Based on the explanation above, it is necessary to have more in-depth research, especially the financial performance of Islamic banking in Indonesia through comparative analysis before and during the COVID-19 pandemic.

\section{Literature Review}

\subsection{Previous Research}

Haule's (2017) research on comparative analysis of financial performance of domestic and foregn banks in Tanzania. The data analysis used was ANOVA analysis. The results showed that there was no significant difference in mean profitability between peer bank groups in terms of ROA and NIM. But there are significant mean differences between peer bank groups.

Haque's (2014) research on comparison on financial performance of commercial banks: A case study in the Context of India. The analysis used was ANOVA. The results showed that there was no significant mean difference in profitability between the various banking groups with respect to ROA and NIM. However, there is a significant difference in terms of ROE.

Research by Nugroho, et al (2019), entitled a comparison analysis of Islamic Commercial Banks with Sharia Business Units from the Efficiency Aspect. The study used independent sample $t$ test analysis. The results show that there is no difference in the average ROA between Islamic Commercial Banks and Sharia Business Units.

Fitriani's research (2020) entitled a comparative analysis of the financial performance of Islamic commercial banks during the Covid 19 pandemic. The data analysis used is the analysis of the two difference test averages. The results show that there are significant differences in the financial performance of BRI Syariah and BNI Syariah in the ratio of NPF, ROA, and BOPO. Meanwhile, there is no significant difference in the FDR ratio between BRI Syariah banks and BNI Syariah banks.

Surya and Asiyah's research (2020) on a comparative analysis of the financial performance of BNI Syariah and Bank Syariah Mandiri during the Covid 19 Pandemic. Data analysis used is the independent $t$ test analysis. The results show that there is a difference between the financial performance of BNI Syariah and Bank Syariah Mandiri in terms of ROA, NPF, and BOPO and while in terms of CAR and ROE aspects, it shows that there is significantly no difference between BNI Syariah and Bank Syariah Mandiri.

\subsection{Financial Performance}

Financial performance is an analysis carried out to assess the extent to which a company has implemented proper and correct financial implementation rules (Fahmi, 2012). Rudianto

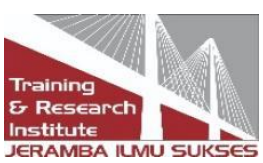


(2013) also states that financial performance is a result or achievement that has been achieved by company management in carrying out its function of managing company assets effectively during a certain period.

To measure financial performance, financial ratio indicators are used. According to Fahmi, 20120) that financial ratios are an instrument of company performance analysis that explains various financial relationships and indicators, which are intended to show changes in financial conditions or past operating performance and help describe the role of these change patterns. The ratios used in this study consist of liquidity ratios, solvency ratios, and profitability ratios.

\section{Research Method}

This research is a comparative research, where according to Tersiana (2018) comparative research is a study that is to compare one variable with another. This type of research was chosen to achieve the research objective (Fauzi, Dencik, \& Asiati, 2019), namely the comparison of the financial performance of Islamic banking before and during the COVID-19 pandemic with the research objects consisting of 14 Islamic Commercial Banks (BUS) and 20 Islamic Business Units (UUS) in Indonesia. The research data used is quantitative data sourced from Islamic banking financial reports on the official website of the Financial Services Authority (OJK) from June 2019 to August 2020. Sampling was carried out using purposive sampling technique, with the following criteria: (1) The selected bank is a bank registered with the Financial Services Authority (OJK); (2) The bank has a complete report related to the research variables; (3) The bank has officially published financial reports on the official website of the Financial Services Authority in succession from June 2019 to August 2020; (4) The data used is data that is normally distributed.

The variables used consist of:

1. Liquidity ratio

This ratio is used to measure the ability of banks to meet all short-term liabilities. The liquidity ratio is reflected by the Non Performing Financing (NPF) variable.

2. Solvability Ratio

The solvency ratio is a measure of the ability of banks to find sources of funds to finance their activities, which is reflected in the Capital Adequacy Ratio (CAR) variable.

3. Rentability Ratio

The rentability ratio is used to measure the level of business efficiency and profitability achieved. This ratio is reflected by variable Return On Assets (ROA).

To test the hypothesis, the analysis used is the multivariate analysis of variance (MANOVA) difference test. According to Basyith et al (2018) that MANOVA is one of the developments of ANOVA analysis, which consists of several treatments with different levels. Before the MANOVA analysis, it was confirmed that the data were normally distributed using the Kolmogorov-Smirnov.

\section{Findings and Discussions}

Based on the results of the analysis, the results of this study are:

\subsection{Normality Analysis}

Data normality analysis is used to determine whether the data to be analyzed by different tests comes from normally distributed data or not. The results of data normality testing can be seen

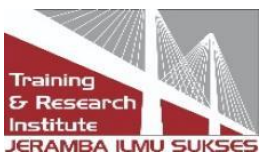


in the following table.

Table 1. Normality Test

\begin{tabular}{lr|r|r}
\hline & \multicolumn{3}{c}{ Kolmogorov-Smirnova } \\
\cline { 2 - 4 } & Statistics & Df & \multicolumn{1}{c}{ Sig. } \\
\hline Non Performing Financing &, 109 & 28 &, $200^{*}$ \\
Capital Adequacy Ratio &, 091 & 28 &, $200^{*}$ \\
Return On Assets &, 139 & 28 &, 175 \\
\hline
\end{tabular}

Table 1 above shows the value obtained from the results of the analysis of the normality test using Kolmogorov Smirnov on the non-performing financing variable, namely 0.200; capital adequacy ratio variable, namely 0.200 ; and the Return on Assets variable that is equal to 0.175 . These values are greater when compared to the alpha value of 0.05 . So it can be concluded that all the data used are normally distributed and can be continued in the MANOVA analysis.

\subsection{Multivariate Analysis of Variance (MANOVA)}

The manova test is used to determine differences in the financial performance of Islamic Commercial Banks and Sharia Business Units before and during the COVID-19 pandemic in Indonesia. The results of this analysis can be seen in the following table.

Table 2. Multivariate Test

\begin{tabular}{|c|c|c|c|c|c|c|}
\hline & Effect & Value & $\mathrm{F}$ & $\begin{array}{c}\text { Hypothesis } \\
\text { df }\end{array}$ & Df error & Sig. \\
\hline \multirow{4}{*}{$\begin{array}{l}\text { Financial } \\
\text { performanc } \\
\text { e }\end{array}$} & Pillai's Trace & 1,659 & 9,896 & 9,000 & 72,000 &, 000 \\
\hline & Wilks' Lambda &, 004 & 52,075 & 9,000 & 53,693 &, 000 \\
\hline & Hotelling's Trace & 86,046 & 197,588 & 9,000 & 62,000 &, 000 \\
\hline & Roy's Largest Root & 84,079 & $672,632 c$ & 3,000 & 24,000 &, 000 \\
\hline
\end{tabular}

Table 2 above shows the significance value of Pillai's Trace, Wilks' Lambda, Hotelling's Trace, and Roy's Largest Root each of 0.000, smaller than the alpha value of 0.05 . So it can be concluded that there is a significant difference in the financial performance of Islamic banking BUS and UUS before and during the COVID-19 pandemic in Indonesia.

\subsection{Main Effect Test}

The main effect test is used to determine whether there is a significant effect based on before and during the Covid 19 pandemic on the financial performance of Islamic banking. The results of this analysis can be seen in the following table.

Table 3. Main Effect Test

\begin{tabular}{|l|c|c|c|c|c|c|}
\hline \multicolumn{1}{|c|}{ Source } & $\begin{array}{c}\text { Dependent } \\
\text { Variable }\end{array}$ & $\begin{array}{c}\text { Type III Sum of } \\
\text { Squares }\end{array}$ & df & Mean Square & $\mathrm{t}$ & Sig. \\
\hline \multirow{2}{*}{$\begin{array}{l}\text { Financial } \\
\text { performance }\end{array}$} & $\mathrm{NPF}$ & 1,573 & 3 &, 524 & 24,900 &, 000 \\
\cline { 2 - 7 } & $\mathrm{CAR}$ & 215,486 & 3 & 71,829 & 486,700 &, 000 \\
\cline { 2 - 7 } & $\mathrm{ROA}$ & 1,275 & 3 &, 425 & 23,452 &, 000 \\
\hline
\end{tabular}

Table 3 above, shows:

1. Effect Non Performing Financing (NPF)

The significance value of the Non Performing Financing (NPF) variable is 0.000 smaller than the alpha value of $0.05(0.000<0.05)$. So it can be concluded that before

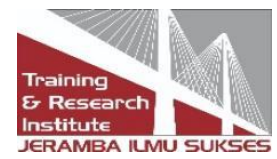


and during the Covid 19 pandemic had a significant effect on NPF.

2. Effect Capital Adequacy Ratio (CAR)

The significance value of the Capital Adequacy Ratio (CAR) variable, which is 0,000 , is smaller than the alpha value of $0.05(0,000<0.05)$. So it can be concluded that before and during the COVID-19 pandemic it had a significant effect on CAR.

3. Effect Return On Assets (ROA)

The significance value of the Return on Assets (ROA) variable, which is 0,000 , is smaller than the alpha value of $0.05(0,000<0.05)$. So it can be concluded that before and during the Covid 19 pandemic had a significant effect on ROA.

\subsection{Post Hoc Test}

Testing is a follow-up test used to find out which group has differences from each of the analyzed variables. The post hoc test consists of 2 types, namely the Bonferroni test and the Howell games test. The choice of this test really depends on the value of the Levene's Test homogeneity. If the Levene's test value is greater than the alpha value (sig.> 0.05 ) then the Bonferroni test is most appropriate. Conversely, if the Levene's Test homogeneity value is smaller than the alpha value ( $\operatorname{sig}<0.05$ ), the games Howell test is the most appropriate. The results of the homogeneity test can be seen in the following table.

Table 4. Homogeneity Analysis

\begin{tabular}{|l|c|c|c|c|c|}
\hline & F & df1 & df2 & Sig. & Information \\
\hline Non Performing Financing & 5,974 & 3 & 24 & .003 & Test the Howell Games \\
\hline Capital Adequacy Ratio & .595 & 3 & 24 & .624 & Test Bonferroni \\
\hline Return On Assets & 2,400 & 3 & 24 & .093 & Test the Howell Games \\
\hline
\end{tabular}

The results of the post hoc test can be seen in the following table.

Table 5. Post Hoc Test

\begin{tabular}{|c|c|c|c|c|c|c|}
\hline \multicolumn{2}{|c|}{ Dependent Variable } & (I) $\mathrm{X}$ & (J) $\mathrm{X}$ & $\begin{array}{c}\text { Mean } \\
\text { Difference }\end{array}$ & Std. Error & Sig. \\
\hline \multirow[t]{6}{*}{ NPF } & \multirow[t]{6}{*}{ Games-Howell } & \multirow[t]{3}{*}{ BUS Before } & BUS Over & .0342 & .03746 & .798 \\
\hline & & & UUS Before & $.5672 *$ & .07706 & .000 \\
\hline & & & UUS Over & .2022 & .07642 & .121 \\
\hline & & \multirow[t]{2}{*}{ BUS Over } & UUS Before & $.5330 *$ & .07445 & .000 \\
\hline & & & UUS Over & .1680 & .07378 & .206 \\
\hline & & UUS Before & UUS Over & $-.3650 *$ & .09990 & .016 \\
\hline \multirow[t]{6}{*}{ CAR } & \multirow[t]{6}{*}{ Bonferroni } & \multirow[t]{3}{*}{ BUS Before } & BUS Over & -.5438 & .21428 & .108 \\
\hline & & & UUS Before & $5.4260 *$ & .18667 & .000 \\
\hline & & & UUS Over & $5.2256 *$ & .20247 & .000 \\
\hline & & \multirow[t]{2}{*}{ BUS Over } & UUS Before & $5.9698 *$ & .21901 & .000 \\
\hline & & & UUS Over & $5.7693 *$ & .23262 & .000 \\
\hline & & UUS Before & UUS Over & -2004 & .20747 & 1,000 \\
\hline \multirow[t]{6}{*}{ ROA } & \multirow{6}{*}{ Games-Howell } & \multirow[t]{3}{*}{ BUS Before } & BUS Over & .1429 & .09365 & .489 \\
\hline & & & UUS Before & $-.2399 *$ & .04524 & .000 \\
\hline & & & UUS Over & $-.4611 *$ & .07673 & .002 \\
\hline & & \multirow[t]{2}{*}{ BUS Over } & UUS Before & $-.3827 *$ & .09460 & .034 \\
\hline & & & UUS Over & $-.6040 *$ & .11309 & .003 \\
\hline & & UUS Before & UUS Over & -.2212 & .07788 & .090 \\
\hline
\end{tabular}

Table 5 above shows that:

1. In the Non Performing Financing variable 
a. Score significanceBUS before the BUS during the COVID-19 pandemic was 0.798, which was greater than the alpha value of $0.05(0.798>0.05)$. So it can be concluded that there is no difference between BUS before and during the Covid 19 pandemic.

b. Score significanceThe BUS before the UUS before the Covid 19 pandemic was 0,000 smaller than the alpha value of $0.05(0,000<0.05)$. So it can be concluded that there are differences between BUS and UUS before the Covid 19 pandemic.

c. Score significanceBUS before UUS during the Covid 19 pandemic was 0.121 greater than the alpha value of $0.05(0.121>0.05)$. So it can be concluded that there is no difference between BUS and UUS before and during the Covid 19 pandemic.

d. Score significanceBUS during the UUS before the Covid 19 pandemic, which was 0,000 smaller than the alpha value of $0.05(0,000>0.05)$. So it can be concluded that there are differences between BUS and UUS during and before the Covid 19 pandemic.

e. Score significanceBUS during the UUS during the Covid 19 pandemic was 0.206 greater than the alpha value of $0.05(0.206>0.05)$. So it can be concluded that there is no difference between BUS and UUS during the Covid 19 pandemic.

f. Score significanceUUS before UUS during the Covid 19 pandemic, which is 0.016 , which is smaller than the alpha value of $0.05(0.016>0.05)$. So it can be concluded that there are differences in the UUS before and during the Covid 19 pandemic.

2. In the variable Capital Adequacy Ratio (CAR)

a. Score significanceBUS before the BUS during the Covid 19 pandemic was 0.108 greater than the alpha value of $0.05(0.108>0.05)$. So it can be concluded that there is no difference between BUS before and during the Covid 19 pandemic.

b. Score significanceThe BUS before the UUS before the Covid 19 pandemic was 0,000 smaller than the alpha value of $0.05(0,000<0.05)$. So it can be concluded that there are differences between BUS and UUS before the Covid 19 pandemic.

c. Score significanceThe BUS before the UUS during the Covid 19 pandemic was 0.000 smaller than the alpha value of $0.05(0.000>0.05)$. So it can be concluded that there are differences between BUS and UUS before and during the Covid 19 pandemic.

d. Score significanceBUS during the UUS before the Covid 19 pandemic, which was 0,000 smaller than the alpha value of $0.05(0,000>0.05)$. So it can be concluded that there are differences between BUS and UUS during and before the Covid 19 pandemic.

e. Score significanceBUS during the UUS during the Covid 19 pandemic was 0,000 smaller than the alpha value of $0.05(0,000>0.05)$. So it can be concluded that there are differences between BUS and UUS during the Covid 19 pandemic.

f. Score significanceUUS before UUS during the Covid 19 pandemic, which was 1,000 greater than the alpha value of $0.05(1,000>0.05)$. So it can be concluded that there is no difference in the UUS before and during the Covid 19 pandemic.

3. On the Return On Assets (ROA) variable

a. Score significanceBUS before the BUS during the Covid 19 pandemic was 0.489,

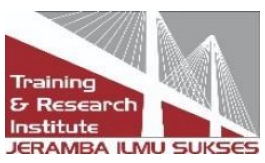


which was greater than the alpha value of $0.05(0.489>0.05)$. So it can be concluded that there is no difference between BUS before and during the Covid 19 pandemic.

b. Score significanceThe BUS before the UUS before the Covid 19 pandemic was 0,000 smaller than the alpha value of $0.05(0,000<0.05)$. So it can be concluded that there are differences between BUS and UUS before the Covid 19 pandemic.

c. Score significanceThe BUS before the UUS during the Covid 19 pandemic was 0.002 smaller than the alpha value of $0.05(0.002>0.05)$. So it can be concluded that there are differences between BUS and UUS before and during the Covid 19 pandemic.

d. Score significanceBUS during the time with the UUS before the Covid 19 pandemic, which was 0.034 , was smaller than the alpha value of $0.05(0.034>0.05)$. So it can be concluded that there are differences between BUS and UUS during and before the Covid 19 pandemic.

e. Score significanceBUS during the UUS during the Covid 19 pandemic was 0.003 smaller than the alpha value of $0.05(0.003>0.05)$. So it can be concluded that there are differences between BUS and UUS during the Covid 19 pandemic.

f. Score significanceUUS before UUS during the Covid 19 pandemic, which was 0.090 , greater than the alpha value of $0.05(0.090>0.05)$. So it can be concluded that there is no difference in the UUS before and during the Covid 19 pandemic.

\subsection{Discussions}

Based on the results of the research data analysis described above, the results obtained are that there are significant differences in financial performance at Islamic Commercial Banks and Sharia Business Units before and during the Covid-19 pandemic. Internal factors such as banking financial performance can be used as a benchmark in paying attention to the development of Islamic banking before and during the Covid-19 pandemic by looking at NonPerforming Financing, Capital Adequacy Ratio, and Return On Assets.

Financial ratios such as Non-Performing Financing, which is to show the ability of bank management to manage non-performing financing that is disbursed by banks to customers, Capital Adequacy Ratio to measure the ability of banks to accommodate the risk of loss that banks may face, Return On Assets to see the ability of banks to use assets to make a profit.

Based on the results of research that has been done, it can be seen that before and during the Covid-19 pandemic had a significant effect on financial performance based on the indicators of Non Performing Financing, Capital Adequacy Ratio, Return On Assets at Islamic Commercial Banks and Sharia Business Units.

\section{Conclusions}

Banking financial institutions are one of the most critical essential institutions in the economy of a country. The financial condition of the banking system, which is reflected in the financial performance of the banking system, can be used as a benchmark for macroeconomic conditions. So it is important to keep it in good condition. The Covid 19 pandemic that has occurred over the past year has resulted in a decline in banking financial performance. However, there are banking financial institutions that are hardly affected by this pandemic, namely Islamic banking financial institutions. Based on the results of the analysis, it is evident that in general there are differences in the financial performance of Islamic banking which

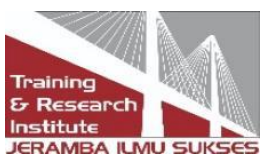


consists of NPF, CAR, and ROA of Islamic Commercial Banks and Sharia Business Units before and during the Covid 19 Pandemic. However, the analysis also proves that Commercial Banks Before and during the COVID-19 pandemic. Does not have a significant difference either from the NPF, CAR, or ROA indicators. Likewise, the Sharia Business Unit before and during the COVID-19 pandemic did not have a significant difference from the CAR and ROA indicators apart from NPF which had a significant difference.

\section{References}

Dencik, A. Basyith., Yahya,F.Fauzi., Yoesoef, M.Idris., Salim, M.Noor (2018) . Statistik Multivariant Analisis ANOVA, MANOVA, ANCOVA, MANCOVA , REPEATED MEASURES dengan Aplikasi EXCEL dan SPSS. Surabaya : Rajawali Pers

Fahmi, Irham (2012). Analisa Laporan Keuangan. Bandung : Alfabeta.

Fahmi, Irham. (2014) . Pengantar Perbankan Teori dan Aplikasi. Bandung : Alfabeta

Fauzi, F., Dencik, A. B., \& Asiati, D. I. (2019). Metodologi Penelitian untuk Manajemen dan Akuntansi. Jakarta: Salemba Empat.

Fitriani, Putri Diesy. 2020.Analisis Komparatif Kinerja Keuangan Bank Umum Syariah pada Masa Pandemi Covid 19. Jurnal Ilmu Akuntansi dan Bisnis Syariah. Volumen 11 (2) : 114 124

Haque, Ansarul. 2014. Comparison of Financial Performance of Commercial Banks: A Case Study in the Context of India (2009-2013). Journal of Financial and Bank Management. Volume 2 (2) : $01-14$

Haule, Bora Gretha. 2017. Comparative Analysis of Financial Performance of Domestic and Foreign Banks in Tanzania. Research Journal of Finance and Accounting. Volume 8 (24) : 77 $-84$

Kasmir. (2014). Analisis Laporan Keuangan. Jakarta : PT Raja Grafindo.

Lucky Nugroho, Fiki Wahyu Kuncoro, Akhmad Amien Mastur. (2019). Analisis Perbandingan Bank Umum Syariah Dengan Unit Usaha Syariah Dari Aspek Efisiensi ; Kualitas Aset Dan Stabilitas Keuangan Periode Tahun 2014-2017. JEPS Vol 6.

Rudianto. (2013). Akuntansi Pengantar . Jakarta : Penerbit Erlangga.

Surya, Yoga Adi., dan Asiyah, Binti Nur. 2020. Analisis Perbandingan Kinerja Keuangan Bank BNI Syariah dan Bank Syariah Mandiri di Masa Covid 19. Iqtishadia: Jurnal Ekonomi dan Perbankan Syariah. Volume 7 (2) : 170 - 187

Tersiana , Andra. (2018). Metode Penelitian . Yogyakarta : Start Up

\section{Copyrights}

Copyright for this article is retained by the author (s), with first publication rights granted to the journal.

This is an open-access article distributed under the terms and conditions of the Creative Commons Attribution license (http://creativecommons.org/licenses/by/4.0/) 